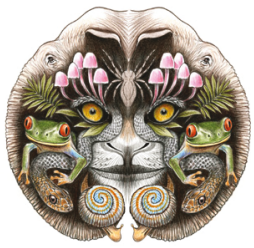

ISSN 0974-7907 (Online) ISSN 0974-7893 (Print)

\title{
RANGE EXTENSION OF TWO POORLY KNOWN ENDEMIC SPECIES OF THE Genus Orophea Blume (ANNONACEAE)
}

OPEN ACCESS

\section{K. Sankararao ${ }^{1}$, N.V. Page ${ }^{2}$, A.N. Sringeswara ${ }^{3}$, R. Arun Singh ${ }^{4}$, Imran Baig ${ }^{5}$ \& Sahana Vishwanath ${ }^{6}$}

${ }^{1,2,4}$ Herbarium, Centre for Ecological Sciences, Indian Institute of Science, Bengaluru, Karnataka 560012, India
${ }^{3,5,6}$ Lead Botanical Garden, University of Agricultural Sciences, GKVK Campus, Bengaluru, Karnataka 560065, India
${ }^{1}$ bharadwaj@ces.iisc.ernet.in (corresponding author), ${ }^{2}$ navendu.page@gmail.com, ${ }^{3}$ ansringesh@gmail.com,
${ }^{4}$ arunrocksin@gmail.com, ${ }^{5}$ imranbaig.dr@gmail.com, ${ }^{6}$ sahana_ans@yahoo.com
Abstract: Orophea malabarica Sasidh. \& Sivar. and Orophea sivarajanii Sasidh., of the family Annonaceae were found growing in close proximity as undergrowth with restricted distribution in the evergreen forest of Makutta Ghat, Kodagu District, Karnataka State, India. Earlier reports suggest that these are endemic to Kerala state of the Western Ghats and found distributed only in their type localities viz., Thrissur and Wayanad districts respectively. However, the present article reports extension of their range to new locations in Karnataka state and therefore become addition to the floral wealth of the state, as they were neither previously collected nor recorded from this region. The updated nomenclature, detailed description, flowering-fruiting seasons, distribution map, scanned herbarium specimens, field photographs, proposed conservation status and other relevant notes are provided in this communication.

Keywords: Endemic, Karnataka, Makutta Ghat, Orophea, range extension, Western Ghats.
Annonaceae is one among the diverse and largest families of the magnolid Angiosperm group with ca. 123 genera and 2100 species distributed world over (Mabberley 2008). The family shows a pantropical distribution along with high levels of endemism at the continental scale (Doyle \& Thomas 1997). The members of this family are mostly trees, shrubs, climbing shrubs and lianas. India is home to 24 genera with 130 species (Kundu 2006) of which 15 genera with 32 species have so far been enumerated from the state of Karnataka (Saldanha 1984; Digital Flora of Karnataka 2014). Species of the genus Orophea Blume in the Western Ghats are poorly studied compared to other genera of
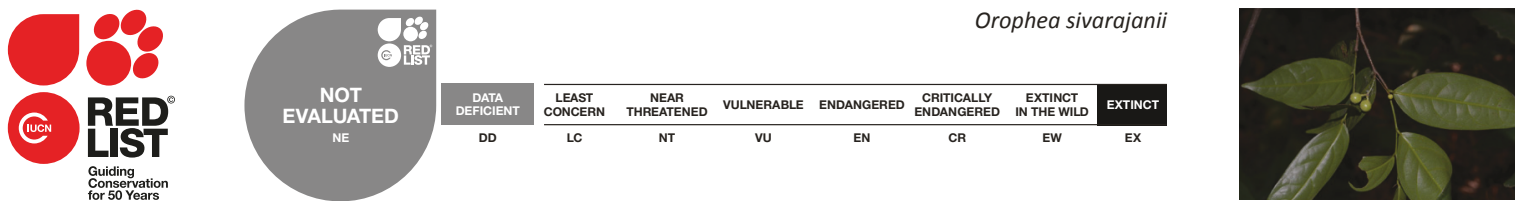

DOI: http://dx.doi.org/10.11609/JoTT.04056.6996-9

Editor: N.P. Balakrishnan, Retd. Joint Director, BSI, Coimbatore, India.

Date of publication: 26 March 2015 (online \& print)

Manuscript details: Ms \# 04056 | Received 07 June 2014 | Final received 08 March 2015 | Finally accepted 09 March 2015

Citation: Sankararao, K., N.V. Page, A.N. Sringeswara, R.A. Singh, I. Baig \& S. Vishwanath (2015). Range extension of two poorly known endemic species of the genus Orophea Blume (Annonaceae. Journal of Threatened Taxa 7(3): 6996-6999; http://dx.doi.org/10.11609/JoTT.04056.6996-9

Copyright: (C) Sankararao et al. 2015. Creative Commons Attribution 4.0 International License. JoTT allows unrestricted use of this article in any medium, reproduction and distribution by providing adequate credit to the authors and the source of publication.

Funding: In-house funding of Indian Institute of Science, Bengaluru; Department of Science and Technology, New Delhi, F.No.SERB/SR/SO/PS/158/2010, dated 10-05-2012

Competing Interest: The authors declare no competing interests.

Acknowledgements: The authors thank the Centre for Ecological Sciences, Indian Institute of Science, Bangalore for facilities and encouragement. The Range Forest Officer, Bhramagiri Wildlife Sanctuary, Kodagu is acknowledged for help in carrying out field explorations in Makutta Ghat forest. Navendu Page acknowledges Rufford small grant foundation for funding the field work and data collection. A.N. Sringeswara acknowledges the Department of Science and Technology, Government of India, New Delhi.

\section{Rufforé,}
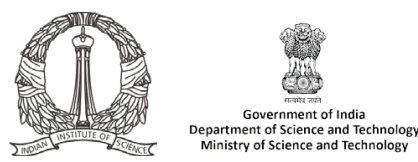
this family. The genus comprises 50 species distributed world over (Mabberley 2008; The Plant List 2013) out of which 12 species occur in India and five of them have been reported as endemic to the Western Ghats (Kundu 2006; Karthikeyan et al. 2009).

\section{Study area}

In our recent field explorations in the Makutta Ghat and adjoining areas in Kodagu District of Karnataka State, the two Orophea species were found growing in close proximity to each other as undergrowth with distribution restricted to the evergreen forests of the Makutta Ghat. The taxa were first detected during January-February 2014 when they were found in flower. During the subsequent visit to other locations in the Makutta Ghat during March-April 2014, these species were observed in the fruiting stage (Fig. 1)

\section{MAterial AND Methods}

Herbarium specimens in both flowering and fruiting stages of the taxa were deposited in Herbarium JCB (Centre for Ecological Sciences, Indian Institute of Science, Bangalore) and digitized. Also, photographs of live specimens and geographical coordinates (using hand held Garmin GPS) along with field notes were recorded. After careful examination of the collection with reference to the available taxonomic literature, digital herbaria and consultation with herbarium UASB (Lead Botanic Garden, University of Agricultural Sciences), the specimens were identified as Orophea malabarica

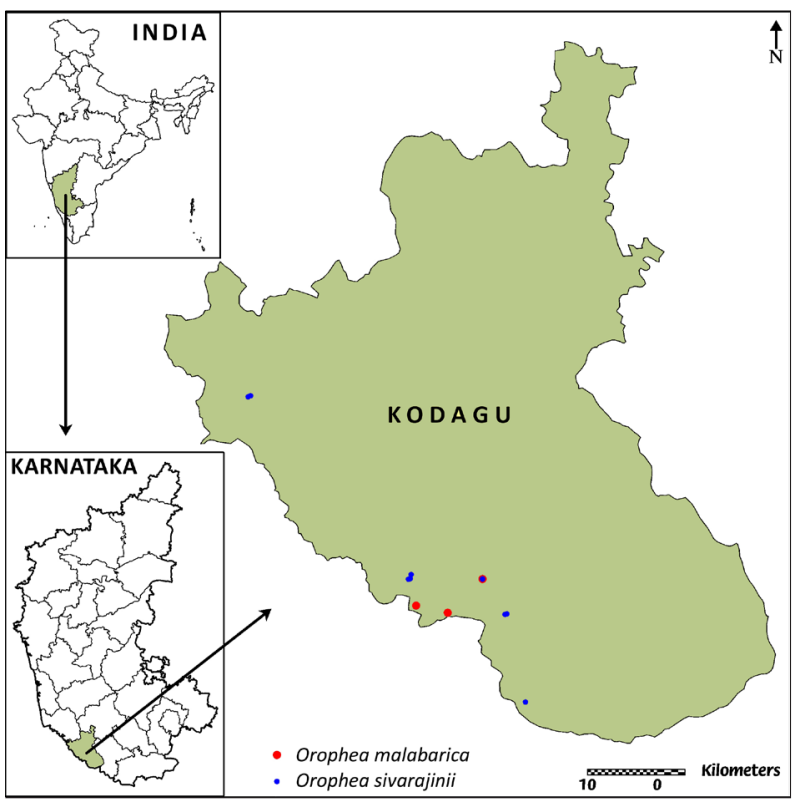

Figure 1. Kodagu District showing the species distribution
Sasidh. \& Sivar. and Orophea sivarajanii Sasidh.

Orophea malabarica Sasidh. \& Sivar., Blumea 35: 269 1990; FI. PI. Thrissur: 29. 1996 (Image $1 \mathrm{~A}, \mathrm{~B}$ \& E).

Moderate-sized shrubs with young shoots pilose. Leaves 5.5-9x2-3.5 cm, oblong or elliptic-oblong, acute, acuminate or obtuse at apex, base obtuse or cuneate, lateral veins 4 or 5 pairs. Petiole short, $2 \mathrm{~mm}$ long, adpressed tomentose. Flowers white, often with pinkish tinge, in 2-3 flowered axillary or extraaxillary, pilose peduncles, bracts ovate-acuminate, densely pilose outside. Pedicels slender, up to $1.5 \mathrm{~cm}$ long, densely pilose. Sepals ovate-rounded, minutely tomentose outside, glabrous inside. Outer petals ovateorbicular, tomentose along margin, $3 \mathrm{~mm}$ across, inner petals glabrous, distinctly clawed, up to $4 \mathrm{~mm}$ long with two narrowly oblong and protruding nectaries. Stamens 6 , all fertile. Carpels 3, glabrous, ovules 2; style hairy; Fruitlets sessile, 1-3, globose, 8-10 mm across, creamy yellow with pink shades.
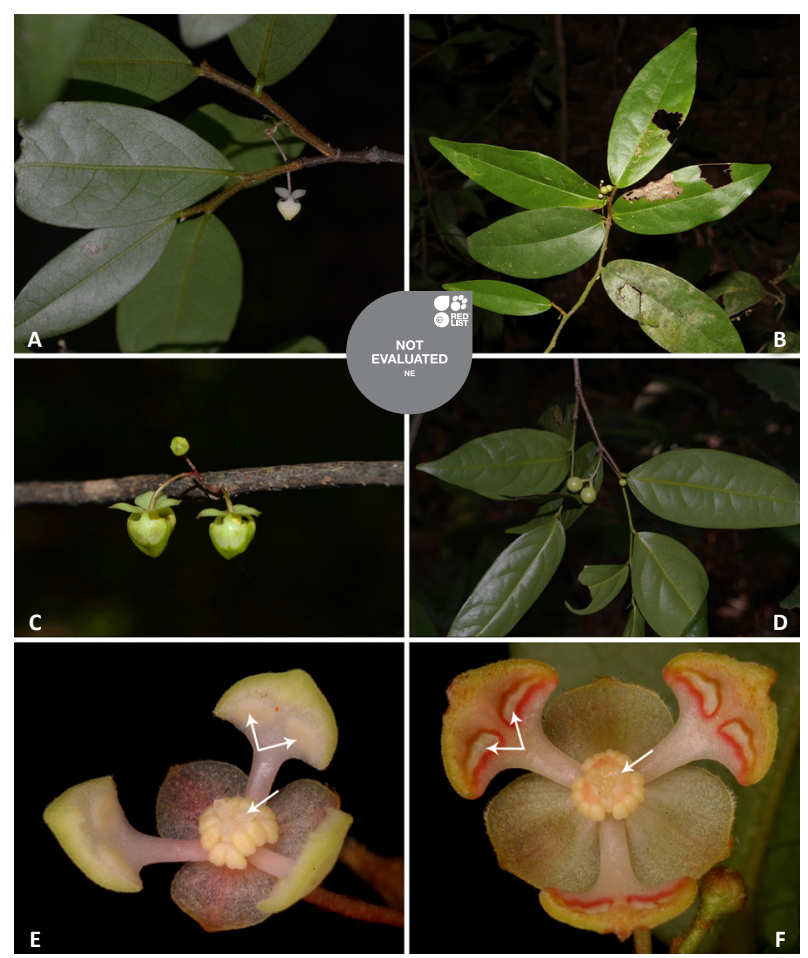

Image 1. Field photographs of live specimens.

A \& B - Flowering and fruiting twigs of Orophea malabarica Sasidh. \& Sivar.; C \& D - Flowering and fruiting twigs of Orophea sivarajanii Sasidh.; E - Single flower showing 3-carpellary gynoecium and 2-oblong protruding nectarines on the inner petals of O.malabarica; F - Single flower showing 6-carpellary gynoecium and 2-pouched nectarines on the inner petals of O.zeylanica.

(C) A-D: R. Arun Singh; E-F: Navendu Page 


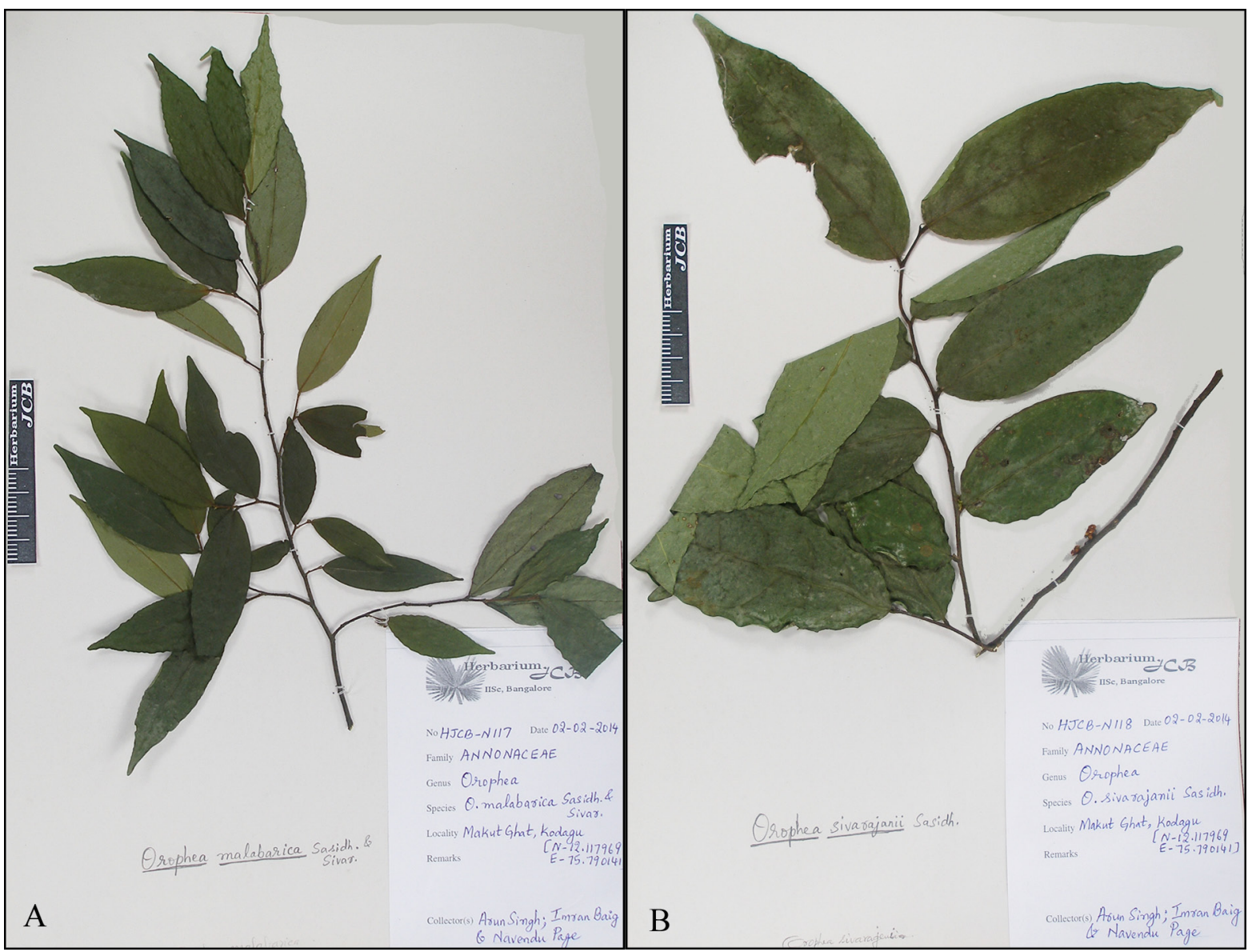

Image 2. Scanned herbarium specimens of A. Orophea malabarica Sasidh. \& Sivar. and B. Orophea sivarajanii Sasidh.

Specimens examined: HJCB-N 117, 02.ii.2014, Kodagu District, Makutta Ghat $\left(12^{\circ} 07^{\prime} 04.69^{\prime \prime} \mathrm{N}\right.$ \& $\left.75^{\circ} 47^{\prime} 24.51^{\prime \prime} E\right)$, deposited at the JCB Herbarium, IISc, Bangalore (Image 2A).

Flowers and Fruits: December-September.

Distribution: Endemic to Western Ghats, India. This species was so far known only from the state of Kerala (Keshavamurthy \& Yoganarasimhan 1990; Sasidharan \& Sivarajan 1990; Sasidharan 2004; Nayar et al. 2006). The recent collection of this species from Kodagu District is a new record of its extended distribution and occurrence in Karnataka.

Note: There are two specimens of this species collected and deposited at the KFRI (Kerala Forest Research Institute) Herbarium (www.kfriherbarium. org/) from parts of Kerala. (a) Accession No. 5785 KFRI, Kerala (Pothiyadippara, Peechi, Thrissur), (b) Accession No. 5710 KFRI, Kerala (Valiyamedu, Peechi, Thrissur). However, there were no specimens of this species deposited at the HIFP (Herbarium Institut Français de Pondichéry) and other regional herbaria.

Orophea malabarica Sasidh. \& Sivar. was first described by Sasidharan \& Sivarajan (1990) from evergreen forests of Peechi, central part of Kerala. Subsequently, Mitra (1993) synonymized it under Orophea zeylanica Hook. f. \& Thomson without giving any justification and same treatment was followed by Mohanan (2005). However, Kundu (2006), Nayar et al. (2006) and Karthikeyan et al. (2009) treated this as a distinct species. We also consider this taxon as a distinct species based on the following distinguishing characters: leaves having 4-5 lateral veins, 3-carpels in gynoecium and two oblong and protruding nectaries on the inner petals in Orophea malabarica, as opposed to leaves having 6-8 lateral veins, 6-12 carpels in gynoecium and two oblong pouched nectaries with large cavities on the inner petals in Orophea zeylanica (Image 1 E \& F).

Orophea sivarajanii Sasidh. in Nordic J. Bot. 19: 341. 1999; Mohanan in FI. Kerala: 159. 2005 (Image 1 C \& D)

Shrubs, 2-3 $\mathrm{m}$ tall with young shoots glabrous. Leaves 7-15 x 3-6 cm, oblong or elliptic-oblong, 
acuminate at apex, obtuse or rounded at base, glabrous, lateral nerves 7-11 pairs, prominent below and faint above. Petiole 2-3 mm long, glabrous. Flowers in axillary or lateral, solitary or 2 or 3 flowered $1.5-2 \mathrm{~cm}$ long racemes. Pedicels $8-12 \mathrm{~mm}$ long, glabrous. Bract $0.5 \mathrm{~mm}$ long, ovate-acute, towards the upper half of the pedicel. Sepals $3,2 \times 2.5 \mathrm{~mm}$, jointed at base, ovatedeltoid, acute, ciliolate along the margins, otherwise glabrous. Petals 6 , in two series, outer petals $4 \mathrm{~mm}$ across, ovate-orbicular, inner petals $7 \mathrm{~mm}$ long (with claw), greenish towards the upper half and white in the lower half, tomentose along the margins. Stamens 12 in two rows of six each. Carpels 6, glabrous, ovules 2, style hairy. Fruitlets globose.

Specimens examined: HJCB-N 118, 02.ii.2014, Kodagu District, Makutta Ghat $\left(12^{\circ} 07^{\prime} 04.69^{\prime \prime} \mathrm{N}\right.$ \& $\left.75^{\circ} 47^{\prime} 24.51^{\prime \prime} E\right)$, with collection number, deposited at the JCB Herbarium, IISc, Bangalore (Image 2B).

Flowers and Fruits: December-February.

Distribution: Endemic to Western Ghats, India. This species was so far known only from the Wayanad District of Kerala (Nayar et al. 2006; Karthikeyan et al. 2009). The recent collection of this species from Kodagu District is a new record of its extended distribution and occurrence in Karnataka.

Note: There is one specimen of this species collected and deposited at the KFRI Herbarium (www. kfriherbarium.org) from Kerala, Accession No. 10844 KFRI, (dated, December 20, 1994) from Kerala (Periyar Reserve Forest, Idukki). There are, however, no specimens of this species collected and deposited at the HIFP, Pondicherry and other regional herbaria.

\section{CONSERVATION STATUS}

The two species of Orophea reported in the present article are poorly known endemics restricted to a narrow stretch of the evergreen forests of the Western Ghats starting from Thrissur District of Kerala and extending into Kodagu District of Karnataka. The population studies and their distribution reports in future need fresh assessment in order to assign it an IUCN conservation status. Based on the data collected from our field explorations and previous reports and as per the criteria of IUCN Red List (IUCN 2013), the authors suggest categorization of Orophea malabarica Sasidh. \& Sivar. and Orophea sivarajanii Sasidh. as threatened species. Anthropogenic factors such as habitat disturbance, land encroachment, deforestation might lead to depletion of their numbers.

\section{REFERENCES}

Digital Flora of Karnataka (2014). An Online Database of Native and Naturalized Vascular Plants of Karnataka <florakarnataka.ces.iisc. ernet.in>

Doyle, J.A. \& A.L. Thomas (1997). Phylogeny and geographic history of Annonaceae. Peographie Physique et Quaternaire 51: 353-361; http://dx.doi.org/10.7202/033135ar

IUCN (2013). IUCN Red List of Threatened Species, version. 2013.2. $<w w w$.iucnredlist.org>

Karthikeyan, S., M. Sanjappa \& S. Moorthy (eds.) (2009). Flowering Plants of India - Vol. 1. Botanical Survey of India, Kolkata, India. li+365pp

Keshavamurthy, K.R. \& S.N. Yoganarasimhan (1990). Flora of Coorg (Kodagu), Karnataka, India. Vimsat Publications, Bangalore, $\mathrm{xv}+711 \mathrm{pp}$.

Kundu, S.R. (2006). A synopsis of Annonaceae in Indian subcontinent: Its distribution and endemism. Thaiszia Journal of Botany 16: 63-85.

Mabberley, D.J. (2008). The Plant Book. A Portable Dictionary of Plants, their Classifications, and Uses. $3^{\text {rd }}$ Edition. Cambridge University Press, Cambridge, xviii+1021.

Mitra, D. (1993). Annonanceae, pp. 202-307. In: Sharma, B.D., N.P. Balakrishnan, R.R. Rao \& P.K. Hajra (eds.). Flora of India - Vol. 1. Botanical Survey of India, Kolkata, India.

Mohanan, N. (2005). Annonaceae, pp. 31-175. In: Daniel, P. (ed.). The Flora of Kerala - Vol. 1. Botanical Survey of India, Kolkata, India.

Nayar, T.S., A.R. Beegam, N. Mohanan \& J. Rajkumar (2006). Flowering Plants of Kerala - A Hand Book. Tropical Botanical Garden Research Institute Publication, Palode, Thiruvananthapuram, Kerala, India, x+1069pp.

Saldanha, C.J. (1984). Flora of Karnataka - Vol. 1. Oxford \& IBH Publishing Company, New Delhi, India, 535pp.

Sasidharan, N. (1999). A new species of Orophea (Annonaceae) from Western Ghats, India Nordic Journal of Botany 19(3): 301-304.

Sasidharan, N. (2004). Biodiversity Documentation of Flowering Plants for Kerala (Part 6). Kerala Forest Research Institute, Peechi, Kerala, India, 702pp.

Sasidharan, N. \& V.V. Sivarajan (1990). Orophea malabarica (Annonaceae): a new species from Peninsular India. Blumea 35: 269-271.

Sasidharan, N. \& V.V. Sivarajan (1996). Flowering Plants of Thrissur Forest (Western Ghats, Kerala). Scientific Publications, Jodhpur, India, 579pp.

The Plant List (2013). A working list of all plant species <www. theplantlist.org>. 